\title{
Effects of medium composition and progesterone on maturation in vitro of rabbit oocytes from Graafian follicles of different sizes
}

\author{
Dianne Moore Smith, J. P. P. Tyler* and G. F. Erickson $\dagger$ \\ Laboratory of Human Reproduction and Reproductive Biology, \\ Departments of Physiology and Obstetrics and Gynecology, \\ Harvard Medical School, Boston, Massachusetts 02115, U.S.A.
}

\begin{abstract}
Summary. Rabbit oocytes from large (1-1.5 mm diam.), medium $(0.5 \mathrm{~mm})$ and small $(0.15-0.25 \mathrm{~mm})$ antral follicles were cultured in five chemically defined media. In all media, oocytes from large antral follicles showed the highest incidence of meiotic activity followed by those from follicles of medium size. Most oocytes from small follicles did not resume meiosis in culture. The addition of glutamine to a standard medium for ovum culture significantly improved maturation of oocytes from mediumsized follicles but did not affect those from large or small follicles. When polyvinylpyrrolidone was substituted for bovine serum albumin, maturation of oocytes from large and medium-sized follicles was reduced. Progesterone at a concentration of $10 \mu \mathrm{M}$ did not affect maturation, but $100 \mu \mathrm{M}$-progesterone blocked germinal vesicle breakdown in oocytes from medium-sized follicles and reduced both germinal vesicle breakdown and polar body formation in oocytes from large follicles. This effect was reversible.
\end{abstract}

\section{Introduction}

There is a positive correlation between the capacity of oocytes to mature in vitro and prepubertal age, follicle size and oocyte diameter in the mouse (Szybek, 1972; Erickson \& Sorensen, 1974; Sorensen, \& Wassarman, 1976) and hamster (Iwamatsu \& Yanagimachi, 1975). In most mammals oocyte growth is complete when the primary follicle reaches $200 \mu \mathrm{m}$ in diameter (multilaminar or early antral stage) (Brambell, 1928, 1956; Moore \& Lintern-Moore, 1974). Following the onset of antrum formation there appear to be species differences in the relationship between follicle size and the capacity of oocytes to resume meiosis in vitro. In mice (Erickson \& Sorensen, 1974), hamsters (Iwamatsu \& Yanagimachi, 1975), pigs (McGaughey, 1977), rhesus monkeys (Smith, Conaway \& Kerber, 1978) and man (D. M. Smith \& K. P. McNatty, unpublished observations) antral follicle size does not appear to influence oocyte maturation in vitro. However, an increased incidence of maturation occurs with increasing follicle size for rabbits (Bae \& Foote, 1975a) and pigs (Tsafriri \& Channing, 1975). Similarly, the effect of progesterone on oocyte maturation appears to show species variation. Progesterone has been reported to enhance maturation of cow (Robertson \& Baker, 1969), rabbit (Robertson \& Baker, 1969; Bae \& Foote, 1975a) and rhesus monkey (Gould \& Graham, 1976) oocytes, to inhibit mouse oocyte maturation in vitro (Nekola \& Smith, 1974; W. K. Cho, personal communication) and not to affect maturation of human (Shea, Baker \& Latour, 1975) or pig (McGaughey 1977) oocytes in culture. Since progesterone production by cultured granulosa cells varies with follicular size in the pig (Channing, 1970) and rabbit (Erickson, Challis \& Ryan, 1974), it was of interest to investigate the effects of antral follicle size and progesterone concentration on oocyte

* Present address: King's College Hospital Medical School, Department of Obstetrics and Gynaecology, Denmark Hill, London SE5 8RX, U.K.

† Present address: Department of Reproductive Medicine, University of California, La Jolla, California 92037, U.S.A. 
maturation in greater detail than previously reported. Rabbit ovaries were chosen because antral follicles of various sizes can be dissected individually and measured accurately. For the study it was necessary to re-examine some of the previous findings on medium composition for optimum maturation of rabbit oocytes (Bae \& Foote, 1975b) and to define a simple culture system suitable for our purposes.

\section{Materials and Methods}

\section{Animals}

Virgin female New Zealand White rabbits $(2 \cdot 2-2 \cdot 7 \mathrm{~kg}$; young adult) were obtained from the White Pine Rabbitry, East Douglas, Massachusetts. Experiments were carried out at all times of the year except during the summer months when breeding performance is poor. Rabbits were killed by cervical dislocation and the ovaries were removed immediately and placed in $5 \mathrm{ml}$ McCoy's 5A medium, modified (Microbiological Associates) in a test-tube on ice.

\section{Oocyte recovery}

One oovary was then placed in an excess of cold McCoy's 5A in a $60 \times 15 \mathrm{~mm}$ Petri dish (Falcon Plastics). Under a dissecting microscope, large preovulatory follicles (1-1.5 $\mathrm{mm}$ in diameter) were punctured with an iris knife to release the follicular contents. Oocytes and cumulus cells were collected in an orally controlled Pasteur pipette and placed in a watch glass containing $2.5 \mathrm{ml}$ of the appropriate culture medium (see below) which had been equilibrated at $37^{\circ} \mathrm{C}$ in an atmosphere of $5 \% \mathrm{CO}_{2}$ in air and $100 \%$ humidity for 1-2 h. Oocytes without an obvious nucleus or those which appeared to be degenerating were discarded. Oocytes of normal appearance and with adherent cumulus cells were washed in equilibrated medium and then placed in 75-100 $\mu$ ldrops (10-12 oocytes/drop) of the same medium under light-weight paraffin oil in $60 \times 15 \mathrm{~mm}$ plastic (Falcon Plastics) tissue culture dishes (Brinster, 1963). When studying the effects of progesterone, oocytes were cultured without an oil overlay in $35 \times 10 \mathrm{~mm}$ dishes containing $2.5 \mathrm{ml}$ control (steroid-free) medium or medium containing different concentrations of progesterone.

When the oocytes from the largest follicles had been placed in culture, the medium-sized antral follicles $(\sim 0.5 \mathrm{~mm}$ in diameter $)$ and small pre- or early antral follicles $(\sim 0.15-0.25 \mathrm{~mm})$ were dissected intact from the remaining ovarian tissue as described by Erickson et al. (1974). Each of these groups of follicles were placed in separate Petri dishes containing McCoy's medium. Medium-sized and small follicles were punctured and the oocytes gently expressed into the surrounding medium with iris knives. These oocytes were washed and placed in culture as described above. Oocytes from one ovary were used in one replicate experiment. After the oocytes from the first ovary had been placed in vitro those from the second were collected and cultured. In experiments in which two rabbits were used, the second animal was killed after the oocytes from the first had been removed, a period of less than $2 \mathrm{~h}$.

\section{Culture techniques}

Oocytes were cultured at $37^{\circ} \mathrm{C}$ in an atmosphere of $5 \% \mathrm{CO}_{2}$ in air, $100 \%$ humidity for $16-20 \mathrm{~h}$ (Chang, 1955). At the end of the culture period, oocytes and adhering follicle cells were placed in $50 \mu \mathrm{l}$ drops of Dulbecco's phosphate-buffered saline (Microbiological Associates) containing 900 i.u. hyaluronidase (Boehringer Mannheim Biochemicals) and pipetted repeatedly to detach the cumulus cells. When the cumulus was totally removed, oocytes were placed in microdrops of fresh culture medium and their stage of maturation was established with the aid of a dissecting microscope $(\times 100)$. They were classified as mature (polar body extruded), meiotically inactive (vesicular nucleus retained), or as having resumed but not completed the first meiotic division (no nucleus or polar body present). Cultured oocytes were scored as degenerate if they showed vacuolization, cytolysis, necrosis or loss of spherical shape. 


\section{Culture media}

Five chemically defined media were used to examine their ability to support maturation of oocytes.

(1) $S M O C$ was the standard medium for culture of mouse ova as described by Biggers, Whitten \& Whittingham (1971). It was modified slightly to contain bovine serum albumin (BSA) (Sigma Chemical Company) $(4 \mathrm{mg} / \mathrm{ml})$ and sodium pyruvate $(0.055 \mathrm{mg} / \mathrm{ml})$ and also contained sodium lactate (Sigma) $(2.95 \mathrm{mg} / \mathrm{ml})$ and glucose $(1 \mathrm{mg} / \mathrm{ml})$.

(2) $S M O C+G L U$ was the modified medium described above supplemented with L-glutamine (Grand Island Biological Co.) $(0 \cdot 22 \mathrm{mg} / \mathrm{ml})$.

(3) McCoy's + BSA : McCoy's 5A medium (without serum, modified) (Microbiological Associates) was supplemented with BSA $(4 \mathrm{mg} / \mathrm{ml})$, sodium pyruvate $(0.055 \mathrm{mg} / \mathrm{ml})$, penicillin (Sigma) (100 i.u./ml) and streptomycin (Sigma) $(50 \mu \mathrm{g} / \mathrm{ml})$. Commercially prepared McCoy's medium contains L-glutamine $(0.22 \mathrm{mg} / \mathrm{ml})$ as well as 20 other amino acids vitamins and glucose $(3 \mathrm{mg} / \mathrm{ml})$, and has been used previously for culturing rabbit granulosa cells (Erickson et al., 1974).

(4) $P V P+G L U$ : the BSA in the SMOC + GLU medium was replaced by polyvinylpyrrolidone (Sigma) ( $4 \mathrm{mg} / \mathrm{ml}$ ) because other studies showed that PVP instead of BSA reduced the concentration of progesterone required to block mouse oocyte maturation in vitro (D. M. Smith, unpublished).

(5) Progesterone-containing media. Because the PVP + GLU medium did not support rabbit oocyte maturation in vitro, progesterone $(10$ or $100 \mu \mathrm{M})$ was added to the SMOC + GLU medium.

\section{Statistical analysis}

Because the number of oocytes cultured in each replicate experiment was small and the frequency of oocytes in each maturation category even smaller, meaningful $\chi^{2}$ tests for homogeneity could not be done. However, replicate results appeared homogeneous and were therefore pooled. The results have been expressed in the form of $2 \times r$ contingency tables, and the significance of treatment effects was determined by calculating and partitioning the appropriate $\chi^{2}$ (Maxwell, 1961).

\section{Results}

As shown in Table 1, a high percentage of the total number of oocytes cultured remained free of visible degeneration after culture in the SMOC, SMOC + GLU and McCoy's + BSA media. A high proportion of oocytes obtained from large antral follicles completed the first meiotic division in all the media, but polar body formation was lower in oocytes from medium-sized follicles and glutamine improved maturation slightly. A small proportion of oocytes from medium-sized follicles resumed meiosis but did not extrude polar bodies. In all three media the majority of oocytes from pre- and early antral follicles retained a nucleus and did not resume meiosis in culture.

The effect of culturing oocytes from large and medium antral follicles in the SMOC + GLU and PVP + GLU media without a paraffin oil overlay is shown in Table 2. The percentage of maturing ova from large and medium follicles cultured in the SMOC+ GLU medium was similar to that observed in experiments in which oil was used (Table 1). When oocytes from large and medium-sized antral follicles were cultured without oil in the PVP + GLU medium, maturation was severely depressed.

The effect of progesterone on maturation of oocytes from large and medium-sized antral follicles is shown in Table 3. Oocyte survival was high in all treatment groups. For oocytes from large antral follicles, progesterone at a concentration of $10 \mu \mathrm{M}$ had no effect on maturation. However, $100 \mu \mathrm{M}$ progesterone reduced the incidence of polar body formation; many oocytes did not resume meiosis, and those which did become meiotically active were unable to extrude polar bodies. Similarly, for oocytes from medium-sized follicles, there was no effect of $10 \mu \mathrm{M}$-progesterone on maturation whereas maturation was reduced by $100 \mu \mathrm{M}$-progesterone. Progesterone affected the oocytes from mediumsized follicles primarily by causing them to remain at the germinal vesicle stage.

Oocytes treated with $100 \mu \mathrm{M}$-progesterone appeared normal after the culture period. Their potential for maturation after removal of the progesterone block was tested: progesterone-treated meiotically inactive oocytes, 8 from large and 13 from medium-sized follicles, were washed and cultured in control medium for another $24 \mathrm{~h}$. Of the oocytes from large antral follicles, only 1 de- 
Table 1. Effect of follicle size and medium composition on rabbit oocyte maturation in vitro

\begin{tabular}{|c|c|c|c|c|c|c|c|}
\hline \multirow[b]{2}{*}{$\begin{array}{l}\text { Follicle type } \\
\text { (diameter) }\end{array}$} & \multirow[b]{2}{*}{$\begin{array}{l}\text { Culture } \\
\text { medium }\end{array}$} & \multirow[b]{2}{*}{$\begin{array}{c}\text { No. } \\
\text { of } \\
\text { exps }\end{array}$} & \multicolumn{5}{|c|}{ Oocytes } \\
\hline & & & $\begin{array}{l}\text { No. } \\
\text { cultured }\end{array}$ & $\begin{array}{l}\text { No. without } \\
\text { signs of } \\
\text { degeneration } \\
\text { after } 16-20 \mathrm{~h} \\
(\%)^{*}\end{array}$ & $\begin{array}{l}\text { No. } \\
\text { forming } \\
\text { 1st polar } \\
\text { body } \\
(\%) \dagger\end{array}$ & $\begin{array}{c}\text { No. } \\
\text { resuming } \\
\text { but not } \\
\text { completing } \\
\text { 1st meiotic } \\
\text { division } \\
(\%) \dagger\end{array}$ & $\begin{array}{c}\text { No. } \\
\text { retaining } \\
\text { a vesicular } \\
\text { nucleus } \\
(\%) \dagger\end{array}$ \\
\hline \multirow{3}{*}{$\begin{array}{l}\text { Large } \\
\text { antral } \\
(1.0-1.5 \mathrm{~mm})\end{array}$} & SMOC & 7 & 44 & $37(84)^{a}$ & $32(86)^{a}$ & $1(3)^{a}$ & $4(11)^{a}$ \\
\hline & SMOC + GLU & 6 & 42 & $39(93)^{a}$ & $36(92)^{2}$ & $1(3)^{a}$ & $2(5)^{a}$ \\
\hline & McCoy's + BSA & 6 & 35 & $31(89)^{a}$ & $29(94)^{a}$ & $1(3)^{a}$ & $1(3)^{a}$ \\
\hline \multirow{3}{*}{$\begin{array}{l}\text { Medium } \\
\text { antral } \\
(0.5 \mathrm{~mm})\end{array}$} & SMOC & 7 & 85 & $69(81)^{a}$ & $22(32)^{b}$ & $19(27)^{b}$ & $28(41)^{b}$ \\
\hline & SMOC + GLU & 6 & 74 & $67(91)^{a}$ & $34(51)^{c}$ & $10(15)^{b}$ & $23(34)^{b}$ \\
\hline & McCoy's + BSA & 6 & 64 & $55(86)^{a}$ & $26(47)^{c}$ & $11(20)^{b}$ & $18(33)^{b}$ \\
\hline \multirow{3}{*}{$\begin{array}{l}\text { Pre- and } \\
\text { early antral } \\
(0.15-0.25 \mathrm{~mm})\end{array}$} & SMOC & 7 & 53 & $42(79)^{a}$ & $1(2)^{d}$ & $3(7)^{a}$ & $38(91)^{c}$ \\
\hline & SMOC + GLU & 6 & 42 & $39(93)^{2}$ & $0(0)^{d}$ & $0(0)^{\mathrm{a}}$ & $39(100)^{c}$ \\
\hline & McCoy's + BSA & 6 & 36 & $32(89)^{a}$ & $1(3)^{d}$ & $2(6)^{a}$ & $29(91)^{c}$ \\
\hline
\end{tabular}

Within columns values with different superscripts differ significantly, $P<0.01$ except for column 6 , b versus c, $P<0.05$.

* Of oocytes cultured.

$\uparrow$ Of oocytes which did not degenerate.

generated, 5 formed polar bodies and 2 resumed but did not complete the first meiotic division. None of the 13 oocytes from medium-sized follicles degenerated: 5 formed polar bodies and 8 resumed meiosis. Although limited, these data for oocytes removed from the influence of progesterone are quite comparable to those obtained for maturation of oocytes from large and medium antral follicles in any of the media in Table 1 and control medium in Table 2.

Table 2. Effect of substituting polyvinylpyrrolidone (PVP: $4 \mathrm{mg} / \mathrm{ml}$ ) for BSA in the SMOC + GLU medium and omitting a paraffin oil overlay on rabbit oocyte maturation in vitro

\begin{tabular}{|c|c|c|c|c|c|c|c|}
\hline \multirow[b]{2}{*}{$\begin{array}{l}\text { Follicle type } \\
\text { (diameter) }\end{array}$} & \multirow[b]{2}{*}{$\begin{array}{l}\text { Culture } \\
\text { medium }\end{array}$} & \multirow[b]{2}{*}{$\begin{array}{c}\text { No. } \\
\text { of } \\
\text { exps }\end{array}$} & \multicolumn{5}{|c|}{ Oocytes } \\
\hline & & & $\begin{array}{l}\text { No. } \\
\text { cultured }\end{array}$ & $\begin{array}{c}\text { No. } \\
\text { without } \\
\text { signs of } \\
\text { degeneration } \\
\text { after } 16-20 \mathrm{~h} \\
(\%)^{*}\end{array}$ & $\begin{array}{c}\text { No. } \\
\text { forming } \\
\text { 1st polar } \\
\text { body } \\
(\%) \dagger\end{array}$ & $\begin{array}{l}\text { No. } \\
\text { resuming } \\
\text { but not } \\
\text { completing } \\
\text { 1st meiotic } \\
\text { division } \\
(\%) \dagger\end{array}$ & $\begin{array}{c}\text { No. } \\
\text { retaining } \\
\text { a vesicular } \\
\text { nucleus } \\
(\%) \dagger\end{array}$ \\
\hline Large & SMOC + GLU & 2 & 14 & $11(79)^{\mathrm{a}}$ & $9(82)^{a}$ & $1(9)^{a}$ & $1(9)^{a}$ \\
\hline $\begin{array}{l}\text { antral } \\
(1.0-1.5 \mathrm{~mm})\end{array}$ & PVP + GLU & 2 & 17 & $16(94)^{a}$ & $2(13)^{b}$ & $1(6)^{a}$ & $13(81)^{b}$ \\
\hline Medium & $\mathrm{SMOC}+\mathrm{GLU}$ & 2 & 63 & $62(98)^{a}$ & $27(44)^{c}$ & $10(16)^{a}$ & $15(40)^{c}$ \\
\hline $\begin{array}{l}\text { antral } \\
(0.5 \mathrm{~mm})\end{array}$ & PVP + GLU & 2 & 47 & $46(98)^{a}$ & $3(7)^{b}$ & $2(4)^{a}$ & $41(89)^{b}$ \\
\hline
\end{tabular}

Within columns values with different superscripts differ significantly, $P<0.01$, except for column 8 , a versus c, $P<0.05$.

* Of oocytes cultured.

$\dagger$ Of oocytes which did not degenerate. 
Table 3. Effect of progesterone (P) added to the SMOC + GLU medium on maturation in vitro of rabbit oocytes from antral follicles of different sizes

\begin{tabular}{|c|c|c|c|c|c|c|c|}
\hline \multirow[b]{2}{*}{$\begin{array}{l}\text { Follicle type } \\
\text { (diameter) }\end{array}$} & \multirow[b]{2}{*}{ Treatment } & \multicolumn{6}{|c|}{ Oocytes } \\
\hline & & $\begin{array}{l}\text { No. of } \\
\text { exps }\end{array}$ & $\begin{array}{c}\text { No. } \\
\text { cultured }\end{array}$ & $\begin{array}{c}\text { No. without } \\
\text { signs of } \\
\text { degeneration } \\
\text { after } 16-20 \mathrm{~h} \\
(\%)^{*}\end{array}$ & $\begin{array}{l}\text { No. forming } \\
\text { 1st polar } \\
\text { body }(\%) \dagger\end{array}$ & $\begin{array}{c}\text { No. resuming } \\
\text { but not } \\
\text { completing } \\
\text { 1st meiotic } \\
\text { division }(\%) \dagger\end{array}$ & $\begin{array}{c}\text { No. retaining } \\
\text { a vesicular } \\
\text { nucleus }(\%) \dagger\end{array}$ \\
\hline $\begin{array}{l}\text { Large } \\
\text { antral } \\
(1.0-1.5 \mathrm{~mm})\end{array}$ & $\begin{array}{c}\text { None } \\
10 \mu \mathrm{M}-\mathrm{P} \\
100 \mu \mathrm{M}-\mathrm{P}\end{array}$ & $\begin{array}{l}4 \\
4 \\
5\end{array}$ & $\begin{array}{l}11 \\
19 \\
18\end{array}$ & $\begin{array}{c}10(91)^{\mathrm{a}} \\
19(100)^{\mathrm{a}} \\
15(83)^{\mathrm{a}}\end{array}$ & $\begin{array}{r}9(90)^{a} \\
19(100)^{a} \\
2(13)^{b}\end{array}$ & $\begin{array}{c}1(10)^{a} \\
0(0)^{a} \\
7(47)^{b}\end{array}$ & $\begin{array}{c}0(0)^{\mathrm{a}} \\
0(0)^{\mathrm{a}} \\
6(40)^{\mathrm{b}}\end{array}$ \\
\hline $\begin{array}{l}\text { Medium } \\
\text { antral } \\
(0.5 \mathrm{~mm})\end{array}$ & $\begin{array}{c}\text { None } \\
10 \mu \mathrm{M}-\mathrm{P} \\
100 \mu \mathrm{M}-\mathrm{P}\end{array}$ & $\begin{array}{l}5 \\
4 \\
5\end{array}$ & $\begin{array}{r}126 \\
82 \\
137\end{array}$ & $\begin{array}{r}109(87)^{\mathrm{a}} \\
69(84)^{\mathrm{a}} \\
105(77)^{\mathrm{a}}\end{array}$ & $\begin{array}{r}35(32)^{\mathrm{b}} \\
26(38)^{\mathrm{b}} \\
2(2)^{\mathrm{c}}\end{array}$ & $\begin{array}{l}26(24)^{\mathrm{b}} \\
21(30)^{\mathrm{b}} \\
18(17)^{\mathrm{a}}\end{array}$ & $\begin{array}{l}48(44)^{\mathrm{b}} \\
22(32)^{\mathrm{b}} \\
85(81)^{\mathrm{c}}\end{array}$ \\
\hline
\end{tabular}

Within columns values with different superscripts differ significantly, $P<0.01$.

* Of oocytes cultured.

+ Of oocytes which did not degenerate.

\section{Discussion}

The present results clearly demonstrate that rabbit oocytes obtained from large (1-1.5 mm) antral follicles have the greatest capacity for maturing in vitro followed by those from medium-sized $(0.5 \mathrm{~mm})$ follicles, while oocytes from small follicles $(0 \cdot 15-0 \cdot 25 \mathrm{~mm})$ do not become meiotically active in culture. These data confirm the trend evident in the data of Bae \& Foote (1975a). However, the follicle size categories in the two studies are not entirely comparable. We classified follicles with a diameter of less than $1.0 \mathrm{~mm}$ as medium-sized or small and therefore obtained more precise information regarding the potential for in-vitro maturation of rabbit oocytes from follicles of different sizes. In the present experiments, the ovaries were placed into cold medium while the oocytes were being recovered, and although this could be considered to have cold-shocked the oocytes (Pincus \& Shapiro, 1940), we believe our results are valid for the following reasons. (1) Replicate data from the two ovaries were identical. (2) Cold shock causes parthenogenetic cleavage of mature mouse oocytes and therefore the number of oocytes dividing to extrude polar bodies would be expected to increase. However, the number of rabbit oocytes with polar bodies decreased with decreasing follicle size and duration of exposure in the cold culture medium. (3) An experiment with mouse oocytes showed no difference in the maturation or degeneration rates of oocytes from chilled ovaries and of those from the contralateral ovaries dissected at $37^{\circ} \mathrm{C}$ (Smith \& Tenney, 1978). (4) The procedures used by Bae \& Foote (1975a) did not involve chilling of the ovaries, but the two sets of results are very similar.

The effect of follicle size on the resumption of meiosis of rabbit oocytes in vitro may be partly dependent on nutritional factors. For example, the composition of the culture medium affected maturation of oocytes from medium-sized antral follicles; the addition of glutamine to a standard mouse ovum culture medium which contained BSA, pyruvate, lactate and glucose increased polar body formation. Similar results were obtained with a more complex medium (McCoy's + BSA) which also contained glutamine, pyruvate and lactate. These data are in agreement with those reported by Bae \& Foote $(1975 b$, c) who found an improvement in oocyte development after the addition of glutamine to a salt-carbohydrate-BSA medium. Bae \& Foote (1975c) also showed that the glutamine was incorporated into acid-precipitable material and into ${ }^{14} \mathrm{CO}_{2}$ during maturation in vitro and that cumulus cells used more glutamine for energy production than did oocytes while oocytes incorporated more glutamine into protein than did cumulus cells during the culture period. In the present experiments, all the oocytes were surrounded by tightly adhering cumulus cells: none were denuded and none were cultured with sheets of granulosa cells. It is not known, therefore, whether the differences in 
maturation due to nutritional factors were mediated indirectly via the cumulus cells or were the result of direct effects on the oocytes. The beneficial effect of glutamine for maturation of denuded rabbit oocytes (Bae \& Foote, 1975b) suggest that the effect may be direct.

In the present experiments an effect of the culture medium composition on maturation was only observed for oocytes removed from medium-sized antral follicles $(0.5 \mathrm{~mm}$ in diameter). Most oocytes from large follicles (1-1.5 mm) matured in vitro regardless of whether glutamine was present or not, although Bae \& Foote (1975b) found that more oocytes from follicles $>0.1 \mathrm{~mm}$ in diameter matured in the presence of glutamine. Far more important than specific carbon sources appears to be the presence of BSA. If BSA is replaced by PVP, maturation is severely reduced, even in the presence of glutamine, and is not affected by the size of the antral follicles from which oocytes are obtained. This is in contrast to the response of mouse oocytes which mature at high rates in medium containing pyruvate, lactate and glucose, and PVP instead of BSA (D. M. Smith, unpublished observations).

In addition to nutritional factors, it is also possible that the progressive increase in capacity of oocytes to mature in vitro, which seems positively correlated with the growth of rabbit antral follicles, could be due to accompanying changes in hormonal content of the follicular fluid. Pig granulosa cells from large antral follicles produce more progesterone than those from smaller follicles (Channing, 1970), and more porcine oocytes mature in vitro when they are from large antral follicles than from medium-sized or small antral follicles (Tsafriri \& Channing, 1975). Similarly, Erickson et al. (1974) found that rabbit granulosa cells isolated from progressively larger antral follicles produced increasing amounts of progesterone in culture and we have now confirmed that rabbit oocytes from the largest follicles have the greatest potential for maturation in vitro. These and other data have led various authors to suggest a relationship between oocyte maturation and the capacity of the follicle to secrete steroids in response to gonadotrophins (Erickson \& Sorensen, 1974; Bae \& Foote, 1975a; Tsafriri \& Channing, 1975; Hunter, Cook \& Baker, 1976). However, Lieberman et al. (1976) found steroidogenesis unnecessary for LH-induced maturation of rat oocytes in whole follicle cultures, and many steroids inhibit mouse oocyte maturation in vitro (Nekola \& Smith, 1974; D. M. Smith, unpublished results). In the present experiments, progesterone prevented meiotic maturation in vitro irrespective of whether rabbit oocytes were obtained from large or medium-sized follicles. In contrast, Bae \& Foote (1975a) reported that progesterone at a comparable concentration advanced maturation of rabbit oocytes from the largest follicles but had no significant effect on those from smaller follicles. Also in contrast are the results for cultured bovine (Robertson \& Baker, 1969) and rhesus monkey (Gould \& Graham, 1976) oocytes, which are apparently stimulated to mature, and for pig (McGaughy, 1977) and human (Shea et al., 1975) oocytes for which progesterone seems to have no effect on oocyte maturation in vitro.

In the present experiments, the lower $(10 \mu \mathrm{M})$ concentration of progesterone tested had no effect, but the higher $(100 \mu \mathrm{M})$ inhibited oocyte maturation in vitro. Radioimmunoassays of steroids of follicular fluid of precoital rabbit antral follicles (1-2 mm in diameter) indicated a total concentration of $0.75 \mathrm{ng}$ progestagen/mg follicular fluid (YoungLai, 1972). Values of 0.144-4.03 $\mathrm{ng}$ progestagen/ follicle can be calculated from the range of follicular fluid weights given. At $100 \mu \mathrm{M}$-progesterone, rabbit oocytes would have been exposed to $3.145 \mu$ g progesterone/culture drop, much higher than the concentrations which appear to be physiological. In more recent studies, however, McNatty, Hunter, McNeilly \& Sawers (1975) report concentrations of progesterone of $1400 \mathrm{ng} / \mathrm{ml}$ in human follicular fluid during the late follicular phase. This is similar to the effective concentration of progesterone used in the present experiments and well within the range which blocks mouse oocyte maturation in vitro (D. M. Smith, unpublished results). Furthermore, a concentration of $100 \mu \mathrm{M}$-progesterone does not appear deleterious since the rabbit oocytes in the present experiments appeared normal after $16-20 \mathrm{~h}$ in culture and were able to form polar bodies or resume meiosis with the expected frequency when washed and transferred to control medium.

Progestagen concentrations in rabbit follicular fluid increase sharply to a peak at $3 \mathrm{~h}$ after coitus or LH injection and fall rapidly to values less than those in precoital or unstimulated follicles by 8 or $9 \mathrm{~h}$ (YoungLai, 1972; Patwardhan \& Lanthier, 1976). A similar pattern is seen in peripheral blood progestagens (Waterson \& Mills, 1976), ovarian venous plasma (Hilliard \& Eaton, 1971) and in cultured intact follicles treated with LH (Mills \& Savard, 1973). The precipitous drop in follicular 
progestagen production approximately $7 \mathrm{~h}$ before ovulation is not inconsistent with our finding that progesterone blocks spontaneous maturation in vitro and that oocytes removed from progesteronecontaining medium can resume and complete the first meiotic division.

We thank Dr K. P. McNatty and Dr J. D. Biggers of criticism for the manuscript, Dr E. Y. Lee for assistance with statistical analyses and Mrs Mary Forte for manuscript preparation. Support was obtained from NICHD Grant Nos. HD 06916 and HD 07923, NIH Center Grant No. HD 06645 , Rockefeller Foundation Grant No. RF 65040 and WHO Research Training Grant No. M8/181/4/T. 87.

\section{References}

BAE, I.-H. \& Foote, R.H. (1975a) Effects of hormones on the maturation of rabbit oocytes recovered from follicles of various sizes. J. Reprod. Fert. 42, 357-360.

BAE, I.-H. \& Foote, R.H. (1975b) Carbohydrate and amino acid requirements and ammonia production of rabbit follicular oocytes matured in vitro. Expl Cell Res. 91, 113-118.

BAE, I.-H. \& FOOTE, R.H. (1975c) Utilization of glutamine for energy and protein synthesis by cultured rabbit follicular oocytes. Expl Cell Res. 90, 432-436.

Biggers, J.D., Whitten, W.K. \& WhittinghaM, D.G. (1971) The culture of mouse embryos in vitro. In Methods in Mammalian Embryology, pp. 86-116. Ed. J. C. Daniel, Jr. W. H. Freeman and Co., San Francisco.

Brambell, F.W.R. (1928) The development and morphology of the gonads of the mouse. Part III. The growth of the follicles. Proc, $R$. Soc. B 103, 258-272.

BRAMBeLl, F.W.R. (1956) Ovarian changes. In Marshalls Physiology of Reproduction, 3rd edn, Vol. 1, Part 1, pp. 455-457. Ed. A. S. Parkes. Longmans Green, London.

Brinster, R.L. (1963) A method for in vitro cultivation of mouse ova from two-cell to blastocyst. Expl Cell Res. 32, 205-208.

Chang, M.C. (1955) The maturation of rabbit oocytes in culture and their maturation, activation, fertilization and subsequent development in the Fallopian tubes. J. exp. Zool. 128, 379-405.

Channing, C.P. (1970) Effects of the stage of the estrous cycle and gonadotropins upon luteinization of porcine granulosa cells in culture. Endocrinology 87, 156-164.

ERICKSON, G.F. \& SORENSEN, R.A. (1974) In vitro maturation of mouse oocytes isolated from late, middle, and pre-antral Graafian follicles. J. exp. Zool. 190, 123-127.

Erickson, G.F., Challis, J.R.G. \& Ryan, K.J. (1974) A developmental study on the capacity of rabbit granulosa cells to respond to trophic hormones and secrete progesterone in vitro. Devl Biol. 40, 208-224.

Gould, K.G. \& Graham, C.E. (1976) Maturation in vitro of oocytes recovered from prepubertal rhesus monkeys. J. Reprod. Fert. 46, 269-270.

Hilliard, J. \& Eaton, L.W. (1971) Estradiol-17ß, progesterone and $20 \alpha$-hydroxypregn-4-en-3-one in rabbit ovarian venous plasma. II. From mating through implantation. Endocrinology 89, 522-527.
Hunter, R.H.F., Cook, B. \& BAKer, T.G. (1976) Dissociation of response to injected gonadotropin between the Graafian follicle and oocyte in pigs. Nature, Lond. 260, 156-158.

IWAMATSU, T. \& YaNAGIMACHI, R. (1975) Maturation in vitro of ovarian oocytes of prepubertal and adult hamsters. J. Reprod. Fert. 45, 83-90.

Lieberman, M.E., TSAFriri, A., Bauminger, S., Collins, W.P., Ahren, K. \& Lindner, H. (1976) Oocytic meiosis in cultured rat follicles during inhibition of steroidogenesis. Acta endocr., Copenh. 83, 151-157.

MaXwell, A.E. (1961) Analyzing Qualitative Data, pp. 11-62. Methuen, London.

MCGAUGHEY, R.W. (1977) The culture of pig oocytes in minimal medium, and the influence of progesterone and estradiol-17 $\beta$ on meiotic maturation. Endocrinology 100, 39-45.

McNatty, K.P., Hunter, W.M., MCNeilly, A.S. \& SAWERS, R.S. (1975) Changes in the concentration of pituitary and steroid hormones in the follicular fluid of human Graafian follicles throughout the menstrual cycle. J. Endocr. 64, 555-571

Mills, T.M. \& Savard, K. (1973) Steroidogenesis in ovarian follicles isolated from rabbits before and after mating. Endocrinology 92, 788-791.

MOORE, G.P.M. \& LINTERN-MOORE, S. (1974) A correlation between growth and RNA synthesis in the mouse oocyte. J. Reprod. Fert. 69, 163-166.

Nekola, M.V. \& Smith, D.M. (1974) Steroid inhibition of oocyte maturation in vitro. Endocrinology 94A, 165, Abstr. 200.

Patwardhan, V.V. \& Lanthier, A. (1976) Effect of an ovulatory dose of luteinizing hormone on the concentration of oestrone, oestradiol and progesterone in the rabbit ovarian follicles. Acta endocr., Copenh. 82, 792-800.

Pincus, G. \& Shapiro, H. (1940) The comparative behavior of mammalian eggs in vivo and in vitro. VII. Further studies on the activation of rabbit eggs. Proc. Am. Phil. Soc. 83, 631-650.

Robertson, J.E. \& BAKeR, R.D. (1969) Role of female sex steroids as possible regulators of oocyte maturation. Proc. 2nd A. Meeting Soc. Study of Reproduction, Davis, Abstr. 57, p. 29.

SheA, B.F., BAKer, R.D. \& LATOUR, J.P.A. (1975) Human follicular oocytes and their maturation in vitro. Fert. Steril. 26, 1075-1082. 
SMITH, D.M. \& TENNEY, D.Y. (1978) The effect of cold shock on mouse oocyte maturation in vitro.J. Reprod. Fert. 54, 401-403.

Smith, D.M., ConaWay, C.H. \& Kerber, W.T. (1978) Influences of season and age on maturation in vitro of rhesus monkey oocytes. J. Reprod Fert. 54, 91-95.

Sorensen, R.A. \& WAssarman, P.M. (1976) Relationship between growth and meiotic maturation of the mouse oocyte. Devl Biol. 50, 531-536.

SzYBEK, K. (1972) In vitro maturation of oocytes from sexually immature mice. $J$. Endocr. 54, 527-528.
TsafriRi, A. \& Channing, C.P. (1975) Influence of follicular maturation and culture conditions on the meiosis of pig oocytes in vitro. J. Reprod. Fert. 43, 149-152.

Waterson, J.W. \& Mills, T.M. (1976) Peripheral blood steroid concentrations in the preovulatory rabbit. $J$. Steroid Biochem. 7, 15-17.

YouNGLAI, E. V. (1972) Effect of mating on follicular fluid steroids in the rabbit. J. Reprod. Fert. 30, 157159.

Received 3 April 1978 